\title{
Penerapan Model Pembelajaran Learning Cycle 5e dalam Meningkatkan Hasil Belajar Siswa
}

\author{
I Komang Gangga Parama Jaya ${ }^{1 *}$, Luh Indrayani ${ }^{2}$ \\ 1,2Universitas Pendidikan Ganesha, Singaraja - Indonesia
}

\section{ARTICLEINFO}

\section{Article history:}

Received September, 6 2020

Received in revised form June, 42021

Accepted June, 42021

Available online June, 28 2021

\author{
Kata Kunci: \\ Hasil belajar IPS, learning \\ cycle $5 E$.

\section{Keywords:} \\ Learning cycle 5E, sosial \\ studies learning outcomes.
}

\begin{abstract}
ABSTRAK
Penelitian ini berangkat dari permasalahan dikelas VII K SMP Negeri 1 Banjar, dimana hasil belajar siswa masih tergolong rendah. Untuk mengatasi permasalahan tersebut peneliti melakukan penelitian penerapan model pembelajaran learning cycle $5 e$. Tujuan penelitian ini adalah untuk mengetahui peningkatan hasil belajar IPS pada kelas VII K SMP Negeri 1 Banjar melalui penerapan model pembelajaran learning cycle $5 e$ dengan materi Kelangkaan dan Kebutuan Manusia, Tindakan, Motif, dan Prinsip Ekonomi. Jenis penelitiannya ialah penelitian tindakan kelas (PTK). Metode pengumpulan data memakai metode observasi dan tes. Jenis datanya ialah data kuantitatif. Berdasarkan hasil penelitian dinyatakan bahwa siklus I hasil belajar siswa memperoleh rata-rata ketuntasan belajar adalah 71,44\%, kemudian siklus II memperoleh rata-rata ketuntasan belajar adalah $85,52 \%$. Hasil penelitian ini membuktikan bahwa hasil belajar IPS dapat meningkat setelah menerapkan model pembelajaran learning cycle 5e di kelas VII K SMP Negeri 1 Banjar.
\end{abstract}

\section{ABSTRACT}

This study departs from problems in class VII K SMP N 1 Banjar, where student learning outcomes are still relatively low. To overcome these problems research into the application of learning cycle 5e. This study is aimed to determine the increase of sosial studies learning outcomes in class VII K SMP Negeri 1 Banjar through the application of learning cycle $5 \mathrm{e}$ of the fourth basic competencies with the material scarcity and human needs, Action, Motif and Economic Principle. The type of the research is Class Action Research (CAR) and the data collected through observation and test method. The type of data is quantitative data. Based on the results of the study stated that the first cycle of student learning outcomes in the first cycle obtain an average learning completeness is $71,44 \%$, then in the second cycle obtain an average learning completeness is $85,44 \%$. Research results prove that sosial studies learning outcomes can increase after applying learning cycle 5e in class VII K SMP Negeri 1 Banjar.

\footnotetext{
* Corresponding author.

E-mail :ganggapj86@gmail.com (Komang Gangga Parama Jaya)
} 


\section{Pendahuluan}

Pendidikan Indonesia yang dikembangkan saat ini adalah paradigma konstruktivistik yaitu teori pembelajaran yang menekankan pada keaktifan siswa untuk mengkonstruksi pengetahuan sendiri. Dalam pandangan konstruktivisme MenurutAunurrahman (2012), "belajar merupakan suatu proses mengkonstruksi pengetahuan melalui keterlibatan fisik mental siswa secara aktif". Peran guru dalam proses pembelajaran yaitu sebagai motivator dan fasilitator. Sedangkan menurut (Ningsih dkk., 2018)bahwa dalam proses pembelajaran konstruktivisme membuat siswa lebih aktif terlibat dengan cara belajar secara mandiri dan mengevaluasi dirinya.

Guru diharapkan dapat memberikan suasana pembelajaran yang nyaman dan menyenangkan. Siswa harus bisa menggali pengetahuan sendiri sehingga siswa tidak akan merasa dipaksa. Proses belajar mengajar dapat tercapai apabila seorang guru mampu menerapkan pendekatan dan menyiapkan model pembelajaran yang sebaik mungkin demi tercapainyatujuan pembelajaran yang diharapkan.

Guru diharapkan menguasai berbagai metode pembelajaran dan menerapkannya didalam kelas. Merancang suatu perencanaan dan pelaksanaan pembelajaran guru harus mengacu pada paradigma baru. Perubahan-perubahan paradigama dan pandangan pendidikan dapat dilihat adanya tuntutan terhadap perubahan proses pembelajaan yang menuntut terjadinya proses pemberdayaan diri dan pengembangan potensi-potensi peserta didik secara menyeluruh (holistik) melalui proses pembelajaran yang dilakukan setiap guru.

Pemilihan metode yang dilakukan oleh guru dalam pembelajaran Ilmu Pengetahuan Sosial (IPS) harus mengacu pada fungsi pendidikan IPS yaitu membangun pemahaman dan mengembangkan keterampilan proses (inkuri) dalam konteks sosial. Kurniawan dkk., (2020)menyatakan bahwa Salah satu masalah yang dihadapi dunia pendidikan adalah menentukan strategi mengajar yang tepat untuk menyampaikan materi pembelajaran" selain itu Menurut Sari (2014)bahwa keberhasilan belajar ditentukan oleh proses siswa dalam belajar. Berangkat dari pernyataan tersebut, keberhasilan proses pendidikan sangat dipengaruhi oleh proses pembelajaran yang berlangsung. Pendidikan merupakan interaksi antara guru dengan siswa untuk menghasilkan sumber daya manusia yang bermutu(Aslindawaty, 2017). Tujuan pendidikan untuk memandu, yaitu mengidentifikasi dan membina serta memupuk, mengembangkan dan meningkatkan bakat tersebut. Upaya peningkatan kualitas dan mengitegrasikan pendidikan IPS senantiasa mengkonkretkan antara ranah kognitif, afektif, dan psikomotor.Dalam ranah kognitif dikatakan bahwa hal-hal tentang manusia harus dapat dinalar agar dijadikan sebagai alat pengabilan keputuan tepat dan rasional. IPS bukan hal yang bersifat hafalan belaka, melainkan yang mendorong daya nalar yang kreatif. Nilai dan sikap tehadap pengetahuan memang penting tetapi nilai dan sikap tehadap masyarakat dan kemanusiaan juga tidak dapat diabaikan, seperti menghargai martabat manusia dan sensitif terhadap perasaan orang lain. Seseorang dianggap telah belajar sesuatu jika dia dapat menunjukkan perubahan perilakunya. MenurutYamin (2008)belajar adalah "bertujuan untuk membentuk pola pikir yang baik", dalam arti cara berfikir siswa dapat digunakan untuk menganalisis suatu permasalahan serta menemukan solusi dalam mengatasi permasalahan tersebut.Keaktifan siswa selama kegiatan pembelajaran sangat dipengaruhi oleh adanya penggunaan model pembelajaran yang diterapkan oleh seseorang guru.

Apabila model pembelajaran yang diterapkan guru kurang memberikan kesempatan siswa untuk terlibat dalam proses pembelajaran, maka siswa hanya akan menjadi pendengar pasif. Keberhasilan belajar siswa sangat ditentukan oleh kemampuan dan ketepatan seorang guru untuk memilih dan menggunakan model pembelajaran(Irhamna dkk., 2017).Berdasarkan paparan tersebut, maka dibutuhkan suatu model pembelajaran yang sesuai bagi siswa yaitu model pembelajaran yang melibatkan siswa dalam proses pembelajaran. Model ini berdasarkan pada teori Piaget dan melibatkan pengajaran dengan pendekatan konstruktivis. Konstruktivistik merupakan salah satu teori pembelajaran yang menuntut peran aktif siswa dalam prosesnya. Peran aktif siswa meliputi pemahaman, kemampuan, nilai, sikap dan minat terhadap suatu materi pelajaran. Salah satu model pembelajaran yang dikembangkan berdasarkan teori konstruktivistik adalah model pembelajaran Learning cycle "5E" (pembelajaran bersiklus). Model pembelajaranlearning cycle $5 e$ merupakan sebuah model pembelajaranyang berpusat pada siswa(Kulsum dan Hindarto, 2011). model pembelajaran ini memperhatikan pengetahuan awal siswa serta memberikan kesempatan siswa untuk lebih memahami konsep-konsep IPS. Model siklus belajar Learning Cycle "5E" merupakan rangkaian tahapantahapan (fase) yang diorganisasikan sedemikiaan rupa sehingga siswa dapat menguasai kompetensikompetensi yang harus dicapai dalam pembelajaran dengan jalan berperan aktif. Model pembelajaran Learning Cycle " $5 E^{\prime}$ " terdiri dari 5 fase yaitu: Engagement, Exploration, Explanation, Elaboration, dan Evaluation yang bertujuan membantu mengoptimalkan cara belajar dengan mengembangkan daya nalar siswa. Siklus belajar merupakan strategi belajar yang sesuai bagi pengajaran IPS dijenjang menengah 
pertama karena model pengajaran ini bersifat fleksibel dan menempatkan kebutuhan yang realistis pada guru dan siswa.

Rendahnya nilai siswa yang ditandai dengan adanya hambatan-hambatan dalam kegiatan pembelajaran, sehingga memerlukan usaha yang lebih giat dan tepat. Dari observasi dan wawancara dengan salah seorang guru bidang studi IPS SMP kelas VII, diperoleh informasi bahwa hasil belajar IPS siswa masih tergolong rendah. Gejala-gejala yang menyebabkan rendahnya hasil belajar IPS siswa dapat disimpulkan sebagai berikut: (1) Pembelajaran masih berpusat pada guru, (2) Kurangnya motivasi belajar karena pembelajaran kurang melibatkan keaktifan siswa dalam proses pembelajaran, (3) Kurangnya minat siswa untuk menemukan atau menggali konsep sendiri, (4) Guru kesulitan dalam memilih metode atau model pembelajaran. Usaha dan strategi yang telah dilakukan oleh guru selama ini ternyata belum bisa mengaktifkan sebagian besar siswa dalam proses pembelajaran di kelas tersebut. Ini disebabkan guru belum sepenuhnya menerapkan model pembelajaran yang membuat semua siswa aktif dan terlibat didalam proses pebelajaran. Adapun siswa yang terlihat aktif hanyalah siswa-siswa yang memiliki daya tangkap di atas ratarata, sedangkan siswa yang memiliki daya tangkap sedang dan lemah tetap telihat pasif. Hal ini dapat dilihat dari hasil belajar yang diproleh dari nilai ulangan tengah semester pada kelas VII yang terdiri dari 11 kelas dengan KKM 60. Dari 11 kelas ternyata nilai IPS banyak yang belum mencapai KKM, terutama pada kelas VII $\mathrm{K}$ dapat dilihat sebagai berikut. Kelas VII A tidak tuntas 8 orang dari 32 peserta didik, kelas VII B tidak tuntas 11 orang dari 32 peserta didik, kelas VII C tidak tuntas 10 orang dari 36 peserta didik, kelas VII D tidak tuntas 13 orang dari 36 peserta didik, kelas VII E tidak tuntas 9 orang dari 36 peserta didik, kelas VII F tidak tuntas 17 orang dari 36 peserta didik, kelas VII G tidak tuntas 14 orang dari 35 peserta didik, kelas VII H tidak tuntas 15 orang dari 36 peserta didik, kelas VII I tidak tuntas 11 orang dari 35 peserta didik, kelas VII J tidak tuntas 20 orang dari 37 peserta didik, kelas VII K tidak tuntas 23 orang dari 38 peserta didik. dari 11 kelas, persentase nilai ketuntasan kelas VII K dikatakan paling rendah berdasarkan wawancara dari guru IPS, sehingga kelas VII K perlu di berikan tindakan. Selain itu Berdasarkan hasil observasi terhadap proses pembelajaran IPS kelas VII K menunjukkan bahwa hasil belajar siswa masih dalam kategori rendah. karena banyak siswa yang belum mampu memenuhi nilai kreteria ketuntasan minimal (KKM) yang diterapkan disekolah. dari data hasil observasi mata pelajaran IPS kelas VII K yaitu, dari 38 ( Tiga puluh delapan) orang siswa, sebanyak 11 (Sebelas) orang siswa atau 28,94\% sudah memenuhi nilai kreteria ketuntasan minimal (KKM), sedangkan sisanya sebanyak 27 (dua puluh tujuh) orang siswa atau 71,05\% tidak memenuhi nilai Kreteria Ketuntasan Minimal (KKM).Berdasarkan dari hasil belajar yang diproleh siswa, terlihat bahwa hasil belajar IPS pada kelas VII K masih banyak yang belum mencapai KKM. Padahal selama ini pihak guru telah menerapkan paradigma baru dan berusaha memberikan yang terbaik dalam pembelajaran namun secara pelaksanaanya belum optimal sehingga hasil belajar siswa belum memenuhi harapan. Ini berarti hasil belajar siswa SMP khususnya pada kelas VII K rendah dan banyak yang belum mencapai ketuntasan minimal. untuk itu kelas VII K perlu diberikan tindakan untuk meningkatkan hasil belajar IPS. Salah satu usaha agar mutu pendidikan dapat ditingkatkan adalah dengan cara memperbaiki proses pembelajaran.

Proses belajar mengajar dapat diperbaiki salah satunya dengan mengadakan Penelitian Tindakan Kelas. Kali ini peneliti melakukan penelitian tindakan kelas terhadap mata pelajaran IPS di kelas VII K. Adapun beberapa model pembelajaran yang sesuai untuk meningkatkan hasil belajar siswa yaitu model pembelajaran Contextual Teacing and Learning, Group Investigation, Jigsaw, Numbered Head Together,Problem Solving dan salah satunya yaitu model pembelajaran Learning Cycle 5E yang dimana model-model pembelajaran tersebut dapat mempengaruhi hasil belajar siswa. Learning Cycle 5E ini dapat memberikan kesempatan siswa untuk membangun dan mengoptimalkan pengetahuannya sendiri. Selain itu, dengan model Learning Cycle " $5 \mathrm{E}$ " siswa dapat berperan aktif untuk menggali, menganalisis, mengevaluasi pemahamannya terhadap konsep yang dipelajari. Dengan demikian, kemampuan analisis, evaluatif dan argumentatif siswa dapat berkembang dan meningkat secara signifikan.

Berdasarkan permasalah yang telah diuraikan maka perlu diadakan penelitian mengenai "Penerapan Model Pembelajaran Learning Cycle 5E Dalam Meningkatkan Hasil Belajar IPS Siswa SMP Kelas VII".

\section{Metode}

Jenis penelitian ini adalah penelitian tindakan kelas. Dengan tujuan meningkatkan hasi belajar IPS melalui penerapan strategi pembelajaran learning cycle 5E. Dalam penelitian ini menggunakan kurang lebih dua siklus yakni dalam siklus terbagi menjadi empat bagian yaitu tahap perencanaan tindakan, tahap pelaksanaan tindakan, tahap observasi atau evaluasi tindakan, dan tahap refleksi tindakan. 


\section{Alur Pelaksanaan PTK}

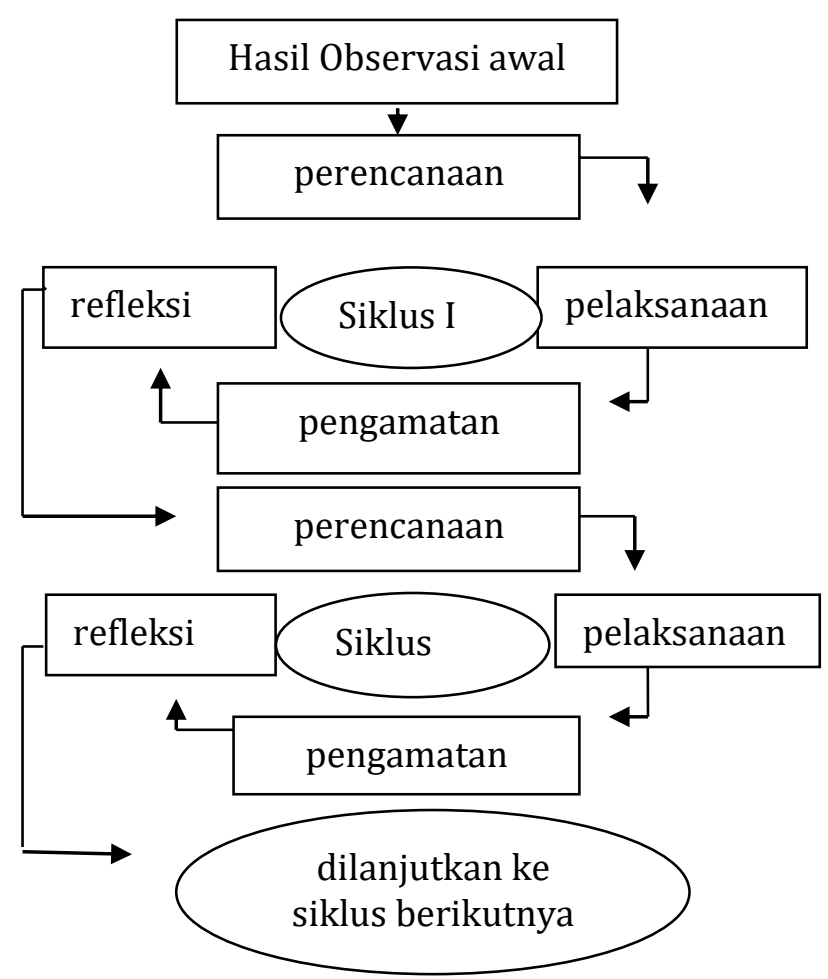

Gambar 1. Rancangan Penelitian Tindakan Kelas

Lokasi penelitian ini ialah di SMP Negeri 1 Banjar. Subjek penelitian ini ialah siswa kelas VII K. Adapun Objek pada penelitian ialah Penerapan Model Pembelajaran Learning cycle 5e dan hasil belajar. Kemudian penelitian ini memakai jenis data kuantitatif. Data kuantitatif dapat menghasilkan hasil belajar setelah diterapkan model pembelajaran learning cycle 5e. Adapun Sumber data yang dipakai ialah data primer. Data primer didapatkan data hasil belajar pada penerapan model Pembelajaran learning cycle 5e.

Metode pengumpulan data hasil belajar memakai metode tes dengan instrument tes berupa soal esai. Setelah data terkumpul maka akan dianalisis menggunakan analisis data deskritif kuantitatif.Data hasil belajar siswa dapat diperoleh dengan rumus berikut.

Rumus untuk mengitung hasil belajar siswa.

1. Untuk mencari skor rata-rata (mean) hasil belajar digunakan rumus sebagai berikut.

$$
M=\frac{\sum f x}{N} \text { (Koyan, 2011) }
$$

$$
\begin{aligned}
& \text { Keterangan: } \\
& \begin{array}{ll}
\mathrm{M} & =\text { Rata-rata kelas } \\
\sum_{\mathrm{N}} f x & =\text { Jumlah sekor seluruh siswa } \\
& =\text { Jumlah siswa }
\end{array}
\end{aligned}
$$

2. Menghitung rata-rata persentase hasil belajar IPS siswa

$$
M(\%)=\frac{M}{S M I} X 100 \% \quad(\text { Koyan, 2011) }
$$

\footnotetext{
Keterangan:

$\mathrm{M}(100 \%) \quad=$ Persentase rata-rata kelas

$\mathrm{M} \quad$ = Rata-rata kelas

SMI = Skor maksimal ideal
} 
Untuk menetukan kreteria keberhasilan digunakan pedoman konversi sebagai berikut.

Tabel 1. Pedoman Konversi Skor Hasi Belajar Siswa

\begin{tabular}{ccc}
\hline No. & Prsentase & Kreteria Hasil Belajar IPS \\
\hline 1 & $80 \%-100 \%$ & $\mathrm{~A}$ \\
2 & $70 \%-79 \%$ & $\mathrm{~B}$ \\
3 & $60 \%-69 \%$ & $\mathrm{C}$ \\
4 & $45 \%-59 \%$ & $\mathrm{D}$ \\
5 & $0-44 \%$ & $\mathrm{E}$ \\
\hline
\end{tabular}

Sumber: pedoman penilaian SMP Negeri 1 Banjar

Untuk menghitung persentase ketuntasan klasikal, dapat dihitung dengan rumus sebagai berikut.

$\mathrm{PKB}=\frac{\text { Jumlah siswa tuntas }}{\text { Jumlah siswa keseluruhan }} \times 100 \%$

Keterangan:

PKB = Persentase Ketuntasan Belajar

Peningkatan hasil belajar siswa ditentukaan siswa dengan membandingkan nilai yang diproleh pada prasiklus I dan siklus II.

\section{Hasil dan Pembahasan}

\section{Data Hasil Belajar Siswa Siklus I}

Penelitian ini dilaksanakan untuk mengetahui apakah penerapan model Learning cycle 5e dapat meningkatan hasil belajar IPS pada siswa kelas VII K di SMP Negeri 1 Banjar setelah diterapkan model pembelajaran Learning cycle 5e. Berdasarkan analisis data hasil belajar siswa pada siklus I yang dilaksanakan 3 kali pertemuan, dengan pembahasan materi Kelangkaan dan Kebutuan Manusia. Maka diproleh hasil tes pada siklus I dapat dilihat pada tabel 2 sebagai berikut.

Tabel 2. Perolehan Hasil Belajar Siswa pada Siklus I

\begin{tabular}{ccccc}
\hline No. & Rentangan Nilai & Kategori Nilai & Jumlah Siswa & Persentase Rata-rata \\
\hline 1 & $80-100$ & Sangat baik & 13 siswa & $34,21 \%$ \\
2 & $70-79$ & Baik & 15 siswa & $39,47 \%$ \\
3 & $60-69$ & Cukup & 2 siswa & $5,26 \%$ \\
4 & $45-59$ & Kurang & 8 siswa & $21,05 \%$ \\
5 & $0<44$ & Sangat kurang & 0 siswa & $0 \%$ \\
& Total & 38 Siswa & $100,00 \%$ \\
\hline
\end{tabular}

Perolehan hasil belajar siswa pada siklus I, dapat dilihat pada Gambar 1 sebagai berikut.

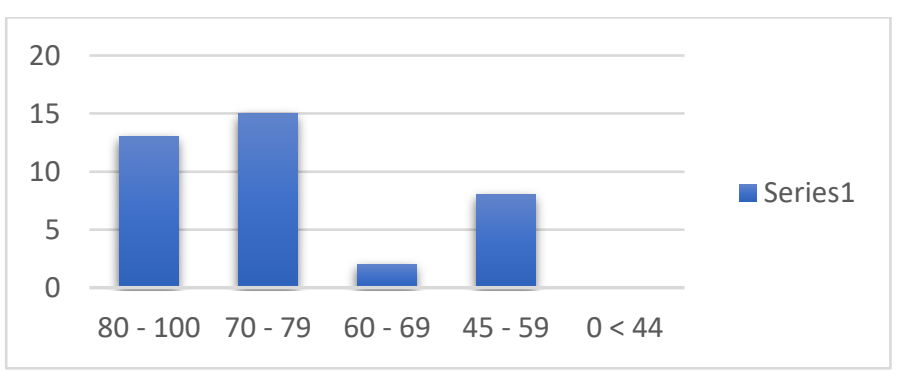

Diagram 1. Diagram Batang Hasil Belajar IPS pada Siklus I 
Berdasarkan gambar di atas pada siklus I, diperoleh data hasil belajar dengan kategori individu sebagai berikut. 13 orang siswa (34.21\%) memperoleh nilai sangat baik, 15 orang siswa (39.47\%) memperoleh nilai dengan kategori baik, 2 orangsiswa (5.26\%) memperoleh nilai dengan kategori cukup, 8 orang siswa (21.05\%) yang mendapat nilai dengan kategori kurang baik, dan tidak ada siswa yang mendapat nilai dengan kategori sangat kurang. Dengan rata-rata hasil belajar yang diperoleh pada siklus I adalah $71,44 \%$ atau masuk dalam kategori baik. Kriteria ketuntasan minimum (KKM) yang diterapkan disekolah pada Mata Pelajaran IPS yaitu sebesar 60. Untuk mengetahui frekuansi ketuntasan belajar siswa dalam Mata Pelajaran IPS SiklusI dapat dilihat pada tabel 3 sebagai berikut.

Tabel 3 Frekuansi Ketuntasan Belajar Siswa dalam Mata Pelajaran IPS Siklus I

\begin{tabular}{lll}
\hline Keterangan & Jumlah Siswa & Presentase \\
\hline Tuntas & 30 siswa & $78,94 \%$ \\
Belum Tuntas & 8 siswa & $21,05 \%$ \\
Jumlah & 38 siswa & $100,00 \%$ \\
\hline
\end{tabular}

Ketuntasan belajar siswa pada siklus I dapat dilihat pada gambar 2 sebagai berikut.

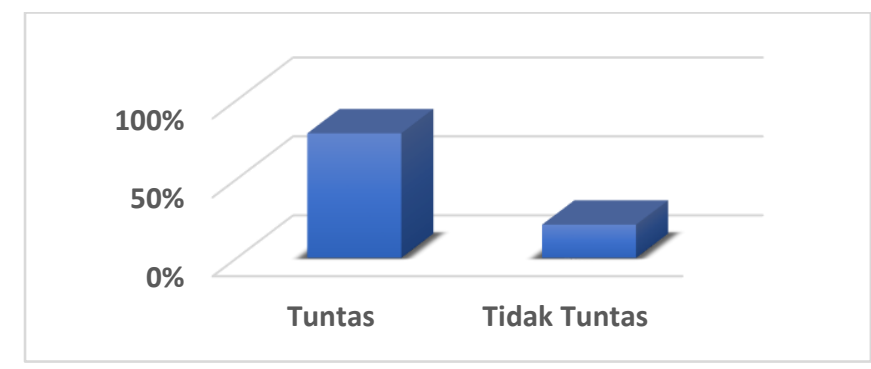

Gambar 2. Diagram persentase ketuntasan hasil belajar siswa pada siklus I

Berdasarkan gambar 2 dapat diketahui siswa yang tuntas sebanyak 30 orang atau 78,94\%, sedangkan siswa yang belum tuntas sebanyak 8 orang atau 21,05\%. Hasil penelitian membuktikan bahwa hasil belajar siswa masih belum mencapai tujuan yang diharapkan, sehingga perlu dilakukan tindakan siklus selanjutnya. Hal ini dilakukan dengan harapan penelitian selanjutnya dapat meningkatkan hasil belajar dengan memperbaiki proses pembelajaran yang telah dilakukan pada siklus I.

\section{Data Hasil Belajar Siswa Siklus II}

Sesuai dengan tujuan dari penelitian ini, maka hasil yang ingin dicapai pada siklus II adalah adanya peningkatan hasil belajar siswa. Berdasarkan hasil penelitian pada siklus I menunjukkan bahwa hasil belajar siswa masih belum mencapai tujuan yang diharapkan, karena pada siklus I masih belum secara utuh dalam pelaksanaannya dan masih terdapat banyak kekurangan dalam pelaksanaan menerapkan model ini, mulai dari siswa yang masih malu-malu untuk mempersentasikan hasil diskusi mereka, sehingga siswa dalam berdiskusi banyak yang lebih memilih diam ketika disuruh mempersentasikan hasil diskusi mereka, selain itu peneliti sebagai guru masih kurang memberi pengetahuan awal sehingga siswa kesulitan dalam memahami materi yang diajarkan dan dari hasil evaluasi pada siklus I masih ada 8 atau 21,05\% siswa yang belum mencapai ketuntasan belajar, sehingga perlu dilakukan perbaikan tindakan siklus berikutnya dengan tujuan mendapatkan hasil yang lebih optimal. Berdasarkan permasalahan yang terjadi pada siklus I perlu diadakan perbaikan tindakan pada siklus II yaitu yang pertama dengan mengintensifkan siswa yang kurang aktif untuk berani menyampaikan pendapat atau menanggapi jawaban dalam kegiatan diskusi dan yang kedua peneliti sebagai guru lebih memperluas dan memperdalam materi yang berhubungan dengan Tindakan, Motif, dan Prinsip Ekonomiagar siswa lebih mudah dalam memahami materi yang diajarkan. Adapun data hasil belajar siswa pada siklus II setelah dilakukan perbaikan proses pembelajaran dengan materi Tindakan, Motif, dan Prinsip Ekonomidapat dilihat pada tabel 4 di bawah ini. 
Tabel 4 Data Hasil Belajar Siswa dalam Mata Pelajaran IPS pada Siklus II

\begin{tabular}{ccccc}
\hline No & Rentangan Nilai & Kategori Nilai & Jumlah Siswa & Persentase Rata-rata \\
\hline & & & & \\
1 & $80-100$ & Sangat baik & 34 siswa & $89.47 \%$ \\
2 & $70-79$ & Baik & 3 siswa & $7.89 \%$ \\
3 & $60-69$ & Cukup & 0 siswa & $0 \%$ \\
4 & $45-59$ & Kurang & 1 siswa & $2.63 \%$ \\
5 & $0<44$ & Sangat kurang & 0 siswa & $0 \%$ \\
& Total & & 38 Siswa & $100 \%$ \\
\hline
\end{tabular}

Berdasarkan gambar di atas dapat disimpulkan bahwa penelitian hasil belajar pada siklus II dengan materi "Tindakan, Motif, dan Prinsip Ekonomi”. Diperoleh data hasil belajar dengan kategori sebagai berikut 34 orang $(89,47 \%)$ memperoleh nilai dengan kategori sangat baik, 3 orang $(7,89 \%)$ memperoleh nilai dengan kategori baik, tidak ada siswa yang memperoleh nilai dengan kategori cukup baik, 1 orang(2,63\%) memperoleh nilai dengan kategori kurang baik dan tidak ada memperoleh nilai dengan kategori sangat kurang.

Berdasarkan nilai mata pelajaran IPS diSMP Negeri 1 Banjar Tahun Pelajaran 2019/2020, maka nilai rata-rata siswa secara klasikal adalah 85,52. Bila dikonversikan ke dalam tingkat penguasaan kompetensi yang berlaku di SMP Negeri 1 Banjar untuk mata pelajaran IPS berada pada rentang 80-100 yang berada dalam kategori sangat baik.

Berdasarkan analisis data pada penelitian tindakan kelas siklus II hasil belajar IPS materi Tindakan, Motif, dan Prinsip Ekonomipada siswa kelas VII K SMP Negeri 1 Banjar Tahun Pelajaran 2019/2020 dapat dilihat pada gambar diagram batang 3 sebagai berikut.

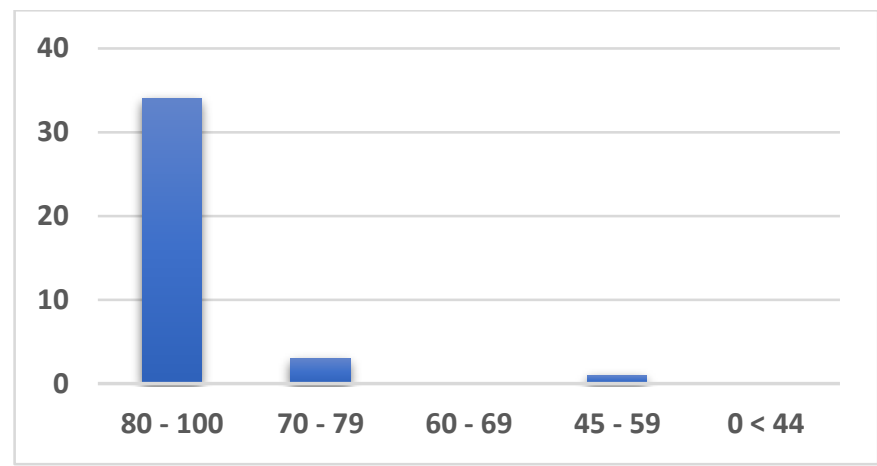

Gambar 3. Diagram Hasil Belajar Siswa dalam Mata Pelajaran IPS pada Siklus II

Berdasarkan gambar di atas, maka dapat dilihat bahwa siswa yang mendapatkan rentangan nilai antara 80-100 atau berada dalam kategori sangat baik sebanyak 34 orang siswa $(89,47 \%)$, rentangan nilai antara 70-79 atau berada dalam kategori baik sebanyak 3 orang siswa (7,89\%), rentangan nilai antara 60-69 atau berada dalam kategori cukup yaitu tidak ada siswa yang termasuk dalam kategori nilai cukup $(0,00 \%)$, dan rentangan nilai antara 45-59 atau berada dalam kategori kurang sebanyak 1 orang $(2,63 \%)$. dan rentangan nilai $0<44$ atau berada dalam kategori sangat kurang yaitu tidak ada siswa dalam kategori sangat kurang. siswa Dengan memperoleh rata-rata pada hasil belajar siswa siklus II adalah $85,52 \%$ atau berada pada kategori sangat baik. Hasil belajar siswa pada siklus II ini mengalami peningkatan di bandingkan pada siklus I, hasil penelitian menunjukkan bahwa strategi pembelajaran learning cycle 5e meningkatkan hasil belajar IPS.

Kriteria Ketuntasan Minimal (KKM) yang diterapkan disekolah SMP Negeri 1 Banjar pada Mata Pelajaran IPS yaitu sebesar 60. Frekuensi ketuntasan belajar siswa dalam Mata Pelajaran IPS Siklus II dapat dilihat pada tabel 5 berikut. 
Tabel 5 Frekuansi Ketuntasan Belajar Siswa dalam Mata Pelajaran IPS Siklus II

\begin{tabular}{cccc}
\hline No & Keterangan & Jumlah Siswa & Presentase \\
\hline 1 & Tuntas & 37 siswa & $97,36 \%$ \\
2 & Belum tuntas & 1 siswa & $2.63 \%$ \\
& Jumlah & 38 siswa & $100,00 \%$ \\
\hline
\end{tabular}

Sebaran ketuntasan belajar siswa pada siklus II dapat dilihat pada gambar diagram 4 sebagai berikut.

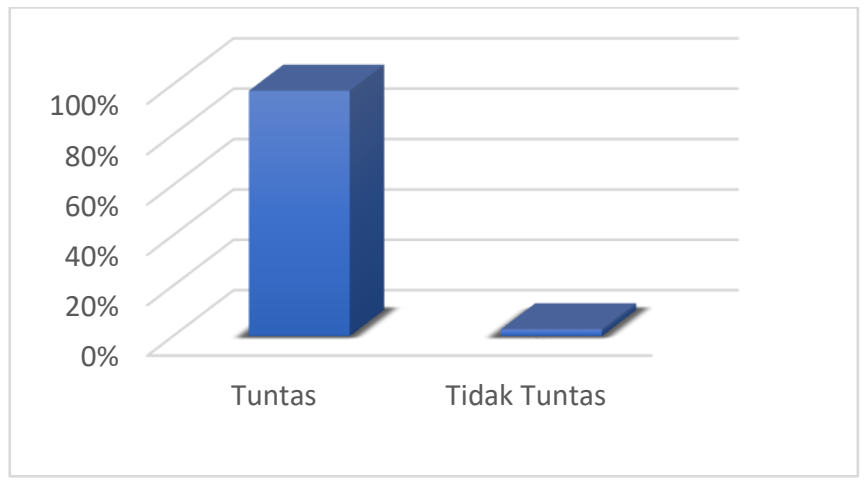

Gambar 4. Diagram Persentase Ketuntasan Hasil Belajar Siswa pada Siklus II

Berdasarkan gambar 4, dapat diketahui siswa yang tuntas sebanyak 37 orang atau 97,36\% sedangkan siswa yang belum tuntas sebanyak 1 orang atau 2,63\%. Hasil penelitian membuktikan bahwa terjadinya peningkatan ketuntasan belajar pada siklus II dibandingkan pada siklus I. Maka dapat dinyatakan penelitian ini meningkatkan hasil belajar siswa, dengan demikian penelitian dihentikan, tidak dilanjutkan ke siklus berikutnya.

\section{Pembahasan}

Berdasarkan hasil penelitian yang dilakukan pada dua siklus dengan menerapkan model pembelajaran learning cycle 5esetelah diberi tindakan pada siklus I, penerapan model pembelajaran learning cycle 5e dapat meningkatkan hasil belajar siswa akan tetapi pada siklus I masih terdapat beberapa kendala sehingga pada siklus I masih belum secara utuh dalam pelaksanaannya dan masih terdapat banyak kekurangan dalam menerapkan model ini, mulai dari siswa yang masih malu-malu untuk mempersentasikan hasil diskusi mereka, sehingga siswa dalam berdiskusi banyak yang lebih memilih diam ketika disuruh mempersentasikan hasil diskusi mereka, selain itu peneliti sebagai guru masih kurang memberi pengetahuan awal sehingga siswa kesulitan dalam memahami materi yang diajarkan dan dari hasil evaluasi siklus I masih ada 8 atau $21,05 \%$ siswa yang belum mencapai ketuntasan belajar, sehingga perlu dilakukan perbaikan tindakan siklus berikutnya dengan tujuan mendapatkan hasil yang lebih optimal. Berdasarkan permasalahan yang terjadi pada siklus I perlu diadakan perbaikan tindakan pada siklus II yaitu yang pertama dengan mengintensifkan siswa yang kurang aktif untuk berani menyampaikan pendapat atau menanggapi jawaban dalam kegiatan diskusi dan yang kedua peneliti sebagai guru lebih memperluas dan memperdalam materi agar siswa lebih mudah dalam memahami materi yang diajarkan.

Pada siklus II diperoleh nilai rata-rata hasil belajar sebesar 85,52\% atau tergolong dalam kategori nilai sangat baik. Data siklus II mengalami peningkatan dari pada siklus I, selain itu ketuntasan belajar juga mengalami peningkatan amat tinggi dari awal observasi ketuntasan belajar sebesar 28,94\% (11 orang) yang tuntas, pada siklus I menjadi 30 orang (78,94\%), dan pada siklus II menjadi 37 orang (97,36\%) yang sudah memenuhi Kreteria Ketuntasan Minimal.

Siklus II menunjukkan hasil belajar siswa sudah adanya peningkatan dari siklus sebelumnya. Sehingga model pembelajaran learning cycle $5 e$ dapat meningkatkan hasil belajar IPS.Pembelajaran dengan menggunakan model pembelajaran learning cycle $5 e$ pada prinsipnya tidak hanya mengajarkan materi saja, tetapi juga ingin mengembangkan kemampuan menguasai materi melalui proses berpikir secara kritis, aktif, kreatif dan beraktivitas sendiri untuk memperoleh pengalaman, pengetahuan, dan pemahaman mampu bekerjasama dengan temannya, mengembangkan keterampilan yang dimiliki serta sudah mulai sangat aktif dan antusias selama proses pembelajaran. Learning cycle 5ejuga melibatkan semua potensi dari siswa, proses mental yang membuat siswa berpikir dan menggunakan segala kemampuannya untuk mencari dan 
menemukan sendiri masalah yang diberikan sehingga dapat memahami materi pelajaran dengan sangat baik.Hal ini sejalan dengan pendapatSaputra (2018),mengatakan bawa learning cycle 5e merupakan salah satu model pembelajaran dengan menggunakan pendekatan konstruktivismedimana model pembelajaraan learning cycle $5 e$ ini dapat digunakan untuk memotivasi siswa dalam memahami gejala-gejala kompleks melalui pengalaman langsung sehingga proses belajar mengajar lebih terpusat pada siswa dan membuat siswa lebih aktif dalam pembelajaran. Sejalan dengan penelitian terdahuluKurniatin (2011) penelitian ini menunjukkan bawa model pembelajaran learning cycle 5e dapat meningkatkan aktivitas dan hasil belajar IPS setelah menerapkan model pembelajaran learning cycle $5 e$. Selanjutnya penelitian yang sependapat dilakukan olehIsnaningtyas (2010) penelitian ini menunjukkan bahwa model pembelajaran learning cycle 5e dapat meningkatkan aktivitas dan hasil belajar siswa pada mata pelajaran ekonomi kelas VIII A SMP Negeri 18 malang.Dan penelitian dariFauziyah dan Abdullah (2018)mengatakan bahwa model learning cycle 5e dapat meningkatkan hasil belajar siswa kelas IV tema 8 di SD Negeri lidah wenten II/462 Surabaya.Jadi penelitian ini menjawab permasalahan yang dirumuskan dibab I, penelitian ini dapat dikatakan berhasil karena tolak ukur keberhasilan yang ditetapkan sudah terpenuhi sesuai yang diharapan. Jadi penerapan model pembelajaran learning cycle 5e dapat meningkatkan hasil belajar IPS Kelas VII K diSMP Negeri 1 Banjar.

\section{Simpulan dan Saran}

Berdasarkan hasil penelitian ini dapat disimpulkan bahwa penerapan model pembelajaran learning cycle 5e dapat meningkatkan hasil belajar IPS kelas VII K di SMP Negeri 1 Banjar. Peningkatan ini dapat dilihat dari siklus I rata-rata penguasaan kompetensi pengetahuan IPS mencapai $(71,44 \%)$ masuk dalam kategori nilai baik. Pada siklus I diperoleh ketuntasan belajar sebanyak 30 orang siswa yang sudah tuntas $(78,94 \%)$ dan 8 orang siswa $(21,05 \%)$ yang belum tuntas. Dan pada siklus II sebesar $85,52 \%$ masuk dalam kategori nilai sangat baik. Maka diperoleh ketuntasan belajar siswa sebanyak 37 orang $(97,36 \%)$ dan siswa yang belum tuntas sebanyak 1 orang $(2,63 \%)$. Dengan demikian penerapa model pembelajaran learning cycle 5 e yang digunakan pada penelitian ini dapat menikatkan hasil belajar denganperubaan peningkatan disetiap siklus.

Bagi siswa di harapkan siswa agar dapat berpartisipasi dan berintraksi secara aktif dalam kegiatan pembelajaran baik antara siswa dengan siswa maupun siswa dengan guru sehingga siswa lebih termotivasi dalam mengikuti pembelajaran yang berdasarkan dengan pengalaman belajar mereka sehingga hasil belajar meningkat.

Kepada guru hasil penelitian ini diharapkan dijadikan refrensi dan pedoman bagi guru dalam meningkatkan kinerjanya dalam merancang pembelajaran dengan tujuan meningkatkan hasil belajar agar lebih optimal. Dengan menerapkan model pembelajaran Learning Cycle 5E menjadi salah satu teknik yang dapat diterapkan guru dalam kegiatan pembelajaran IPS.

Kepada sekolah diharapkan dapat dijadikan pedoman dan untuk motivasi dan meningkatkan kualitas guru-guru dalam merancang pembelajaran yang inovatif dalam pembelajaran siswa sesuai dengan kurikulum 2013 sehingga dapat meningkatkan mutu dan kualitas sekolah.

Bagi peneliti lain diharapkan agar lebih kreatif untuk hasil yang berbeda. peneliti menyarankan kepada peneliti selanjutnya untuk dikembangkan pada mata pelajaran dan tema yang lebih beragam untuk memproleh hasil yang lebih baik.

\section{Daftar Rujukan}

Aslindawaty, N. (2017). Penerapan Model Pembelajaran Learning Cycle 5E (Engagment, Exploration, Explanation, Elboration, Evaluation) untuk Meningkatkan Hasil Belajar Ekonomi. Jurnal Office, 3(1), 1924.

Aunurrahman. (2012). Belajar dan Pembelajaran. Bandung: Alfabeta.

Fauziyah, R., \& Abdullah, M. H. (2018). Model Pembelajaran Learning Cycle 5E Fase. Jurnal Penelitian Pendidikan Guru Sekolah Dasar, 6(9), 1-10.

Irhamna, I., Rosdianto, H., \& Murdani, E. (2017). Penerapan Model Learning Cycle 5E untuk Meningkatkan Keterampilan Berpikir Kritis Siswa Pada Materi Fluida Statis Kelas VIII. Jurnal Fisika Flux: Jurnal Ilmiah Fisika FMIPA Universitas Lambung Mangkurat, 14(1), 61-64.

Isnaningtyas, M. (2010). Penerapan Model Pembelajaran Learning Cycle (Siklus Belajar) untuk Meningkatkan Aktivitas dan Hasil Belajar Mata Pelajaran IPS-Ekonomi Siswa Kelas VIII SMP Negeri 18 Malang. 
Universiras Negeri Malang.

Koyan, I. W. (2011). Asesmen Dalam Pendidikan. Singaraja: Universitas Pendidikan Ganesha Press.

Kulsum, U., \& Hindarto, N. (2011). Penerapan Model Learning Cycle Pada Sub Pokok Bahasan Kalor Untuk Meningkatkan Keaktifan dan Hasil Belajar Siswa Kelas VII SMP. Jurnal Pendidikan Fisika Indonesia, 7(2), $1-10$.

Kurniatin, D. T. (2011). Penerapan Metode Belajar Learning Cycle-5E pada Mata Pelajaran Akuntansi terhadap Siswa Kelas XII IPS 1 untuk Meningkatkan Aktivitas dan Hasil Belajar di SMA Negeri 6 Malang. Universitas Negeri Malang.

Kurniawan, K. H., Muhammad, R. B., \& Idham, M. (2020). Upaya Meningkatkan Hasil Belajar Ekonomi Melalui Model Pembelajaran Learning Cycle Pada Peserta Didik Sma Gajah Mada. Jurnal Elastisitas: Kajian Pendidikan Ekonomi, Ilmu Ekonomi, Dan Kewirausahaan, 2(1), 47-57.

Ningsih, N., Saadi, P., \& Irhasyuarna, Y. (2018). Penerapan Model Learning Cycle 5E Dalam Meningkatkan Motivasi dan Hasil Belajar Siswa Pada Mata Pelajaran Koloid di Kelas XI MIA-3 MAN 1 Banjarmasin. JCAE (Journal of Chemistry And Education), 1(3), 1-10.

Saputra, R. (2018). Penerapan Model Learning Cycle 5E Dibantu Dengan Media Puzzle Untuk Meningkatkan Keterampilan Berpikir Kritis dan Prestasi Belajar Siswa Pelajaran IPS di Kelas IV SD N 2 Karangreja. Universitas Muhammadiyah Purwokerto.

Sari, O. N. (2014). Pengaruh Model Pembelajaran Learning Cycle 5E terhadap Kemampuan Berpikir Kritis Siswa Pada Mata Pelajaran Geografi. Universitas Negeri Malang.

Yamin, M. (2008). Paradigma Pendidikan Konstuktivistik. Jakarta: Gaung Persada Perss. 